\title{
Villet egenskade blant ungdom: nye forsknings- resultater og konsekvenser for forebyggende arbeid
}

\author{
Ved M ette Y stgaard
}

\section{Laerere og ansatte i skolens helse- og rådgiuningstjeneste kommer stadig i kontakt med elever som} påfører seg selv skade ved for eksempel å ta en overdose medikamenter eller kutte og skjare seg forskjellige steder på kroppen. Slik atferd skremmer og skaper ofte usikkerhet hos dem som ønsker å hjelpe. Hva kan slik atferd vaere uttrykk for? - Et ønske om å ta sitt eget liv? - En måte å be om hjelp eller oppmerksomhet på? - En flukt fra en uutholdelig situasjon? - En straff mot seg selv eller andre, eller kanskje et forsøk på å mestre uutholdelig psykisk smerte? Hva kan vi gjøre for å hjelpe? Og ikke minst, hvordan kan skolen møte dette problemet, gjerne før skaden er skjedd?

I denne artikkelen presenterer vi helt ferske resultater fra den såkalte C A SEstudien ( $C$ hild and A dolescent Selfharm in Europe). Studien er et samarbeidsprosjekt mellom flere land i Europa der man prøver å få mer kunnskap om nettopp villet egenskade. H vor vanlig er det, hva dreier det seg om, hva kjennetegner denne risikoutsatte ungdomsgruppen og $\mathrm{i}$ hvilken grad får de tilstrekkelig hjelp, var spørsmålene man stilte seg. Bakgrunnen for studien og forskningsmetodene som er benyttet, er beskrevet tidligere (Y stgaard 2001, Ystgaard et al. 2003). Studien består av en sykehusundersøkelse og en skoleundersøkelse. Vi vil her fokusere på noen av resul tatene fra skoleundersøkelsen og drøfte disse med tanke på forebyggen de arbeid i skolen. M en først en begrepsavklaring.

\section{Begrepet villet egenskade}

En rekke begreper som selvmordsforsøk, selvbeskadigelse, selvdestruktiv atferd, selvmutilering og villet egenskade har vært benyttet for å beskrive og studere selvskadende atferd. Det er ikke alltid klart i hvilken grad disse begrepene beskriver samme, overlappende eller helt forskjellige fenomener. I forskningen på feltet er begrepsbruken ofte forskjellig og til dels uklar. Som felles definisjon for å studere og sammenligne selvskadende atferd blant ungdom i deltakerlandene valgte vi i CA SE-studien begrepet villet egenskade, "intentional self harm", som benyttes som egen kategori i ICD-10 diagnosesystemet, (1998) konkretisert på følgende måte: En handling som ikke endte med døden, hvor individet med vilje gjorde ett eller flere av følgende:

- Initierte atferd (for eksempel kuttet seg selv, hoppet fra en høyde) i den hensikt å skade seg selv
- Tok medikamenter i en mengde utover det som er forskrevet eller som er vanlig anerkjent dose

- Tok illegale stoffer/narkotika i den hensikt å skade seg selv

- Svelget et ikke fordøyelig stoff eller en gjenstand.

Definisjonen er vid, men ganske entydig. Den forutsetter at en har påført seg selv skade med vilje. M en den tar ikke stilling til hensikten eller intensjonen med handlingen og heller ikke til hvor alvorlig den fysiske skaden er. Den skiller derfor ikke mellom selvmordsforsøk og selvpåført skade som en foretar av andre grunner. D efinisjonen gir imidlertid mulighet for å registrere alle former for villet egenskade som ungdommene rapporterer, og deretter studere eventuelle undergrupper ut fra den tilleggsinformasjon de har gitt om måten de skadet seg på og grunnen til at de skadet seg.

I tråd med definisjonen ble ungdommene i CA SE-studien spurt: "H ar du noen gang med vilje tatt en overdose (for eksempel piller eller annen medisin), eller forsøkt å skade deg selv på noen måte ( som å kutte eller skjære deg) ?" Deretter ble elevene som svarte ja, bedt om å beskrive så detaljert som mulig hvordan de skadet seg selv, ved den siste episoden dersom de rapporterte flere episoder. Forskerne kategoriserte disse åpne svarene etter strenge regler for hvorvidt beskrivelsen ungdommene ga tilfredsstilte C A SEgruppens definisjon, og i så fall hvilken metode de hadde brukt da de skadet seg. Spørreundersøkelsen, som inneholdt en rekke skalaer og spørsmål om psykisk hel se, rusmisbruk, negative livshen delser, hjelpsøking og selvtillit, ble gjennomført blant alle elever på første trinn på samtlige videregående skoler i H edmark og 0 ppland (Y stgaard et al. 2003). M ajoriteten av elevene var 15-16 år gamle. Svarprosenten var $91,2 \%(n=4060)$.

\section{Omfang, metode og intensjon}

$434(10,7 \%)$ elever rapporterte handlinger som forskerne klassifiserte som villet egenskade. $266(6,6 \%)$ av disse elevene hadde gjennomført minst en episode i løpet av det siste året. R esultatene i denne artikkelen baserer seg på disse 266 elevene. Blant dem var det omtrent tre ganger så mange jenter $(201 ; 75,6 \%)$ som gutter $(65 ; 24,4 \%)$. Ser vi på hvilke metoder de benyttet, finner vi at så mange som 197 (74,1\%) elever hadde kuttet eller skåret seg opp et eller annet sted på kroppen. 45 (16,9\%) av ungdommene hadde tatt en overdose med medikamenter, hvorav $9(3,4 \%)$ både hadde kuttet seg og tatt en overdose med medikamenter. De resterende 24 (9\%) rapporterte forskjellige andre måter de hadde skadet seg på, som ved for eksempel å hoppe fra høyde, drikke store mengder alkohol (i den uttalte hensikt å skade seg selv), kjøre med moped mot bil eller forsøke å henge seg.

U t fra svarene på det åpne spørsmålet går det tydelig fram at vi har registrert hele spekteret av villet egenskade, fra al vorlige sel vmordsforsøk -"Jeg har prøvd å ta selvmord, prøvde å henge meg ", "Tok paracet, ca 50 stk., ble funnet og kjørt til legevakten" til tilsynelatende mindre alvorlige selvskader -"Bare små kutt oppover armen, ikke noe selvmordsforsøk" eller -"Jeg prøvde å ta masse penicillintabletter, men kunne ikke etter 4 stk." M aterial et gir imidlertid ingen mulighet for å få sikre tall på omfanget av alvorlige og mindre alvorlige somatiske skader.

På spørsmål om hvorfor ungdommene skadet seg selv, viser tabell 1 (neste side) at så mange som $149(56,0 \%)$ svarte at de ønsket å dø, og 171 (64,3\%) at de ønsket å slippe unna en uutholdelig føl else. 


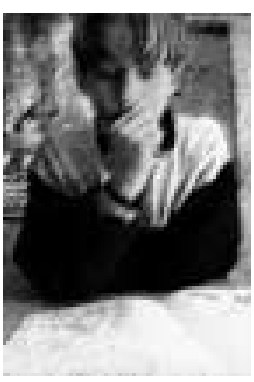

Tabell 1. H vorfor tok elevene en overdose eller skadet seg selv på annen måte?

Jeg ønsket å vise hvor desperat jeg følte meg

Jeg ønsket å dø

Jeg ønsket å straffe meg selv

Jeg ønsket å skremme noen

110

Jeg ønsket å ta igjen for noe som har hendt 58

Jeg ønsket å slippe unna en uutholdelig følelse

Jeg ønsket å finne ut om noen virkelig er glad i meg

171

82

J eg ønsket å få oppmerksomhet
U t fra klinisk erfaring og tidligere forskning kunne en ha antakelser om at de som kuttet seg oftere hadde et ønske om å redusere psykisk smerte, mens de som tok en overdose med medikamenter oftere hadde hatt et ønske om å ta sitt eget liv. Vi finner imidlertid ikke holdepunkter for dette. Det var ingen signifikant forskjell mellom det de som hadde kuttet seg og de som hadde tatt overdoser, oppga som grunner for den selvskadende episoden. Det var heller ingen forskjell i hva gutter og jenter oppga som grunn for selvskaden. Elevene kunne krysse av for flere alternativ. Bare $50(18,8 \%)$ elever oppgav bare én grunn for selvskaden, og så mange som $110(41,4 \%)$ elever svarte at de ønsket både å dø og slippe unna en uutholdelig følelse.

\section{Hva kjennetegner ungdom som skader seg?}

Fra tidligere undersøkel ser, og også fra tidligere publikasjoner fra C A SE-studien, vet vi at ungdom som skader seg med vilje, kjennetegnes ved en rekke forhold som viser at de strever på flere måter. De har mye angst, depresjon og lav selvfølelse. De har også vært utsatt for flere alvorlige livshendelser, som seksuelle overgrep og selvmordsatferd blant venner og i familien og vedvarende bel astninger som mobbing på skolen og alvorlige konflikter hjemme (G roholt et al. 2000, H awton et al. 2002, Y stgaard et al. 2003). Vi vil i det følgende se nærmere på hva som kjennetegner omstendighetene rundt den selvskadende episoden, og i hvilken grad, og i så fall hvor, de har fått hjelp.

\section{Hva er situasjonen rundt den selvskadende episoden?}

$U t$ fra et forebyggende perspektiv er det viktig å vite om elevene handl et impulsivt eller om de lenge hadde tenkt å skade seg selv, hvor de oppholdt seg da de påførte seg skaden, og om det var alkohol med $\mathrm{i}$ spillet. Det er stor variasjon i grad av impulsivitet. 101 (38,0\%) av ungdommene hadde tenkt på det i mindre enn en time, $31(11,7 \%)$ mellom en time og en dag, $67(25,2 \%)$ mellom en dag og en måned, og $53(19,9 \%)$ hadde tenkt på dette en måned eller mer (14 ubesvarte). Så mange som $188(70,7 \%)$ var hjemme da de skadet seg selv, mens ikke flere enn
$57(21,4 \%)$ gjorde dette under påvirkning av alkohol. Det var signifikant flere jenter (150; $74,6 \%$ ) enn gutter (38; 58,5\%) som var hjemme. Det var ingen kjønnsforskjell når det gjaldt å være påvirket av al kohol. Bare 34 (12,8\%) av ungdommene rapporterte at mor visste hva de gjorde den gangen. I 22 (8,3\%) av tilfellene var far kjent med episoden. Det er da tankevekkende at i $164(61,7 \%)$ av tilfellene visste vennene deres om den selvskadende episoden.

\section{Hvor får de hjelp?}

39 av elevene $(14,7 \%)$ hadde fătt behandling på sykehus i forbindelse med den siste selvskadende episoden. Her er det interessant å merke seg at nærmere halvparten av dem som hadde tatt en overdose med medikamenter, hadde vært i kontakt med sykehuset $(21 ; 46,7 \%)$, men bare $12(6,1 \%)$ av dem som hadde kuttet seg selv, hadde vært på sykehus i forbindelse med episoden.

Elevene ble også spurt om de hadde snakket med noen eller prøvd å få hjelp før de skadet seg, og om de hadde fătt hjelp for problemene sine i etterkant. Det var listet opp en rekke alternative personer og hjel peinstanser, og de kunne krysse av for flere. Svarene fremgår av figur 1.

\section{Figur 1. H jelp - før og etter siste episode med villet egenskade ( $\mathrm{N}=266$ )}

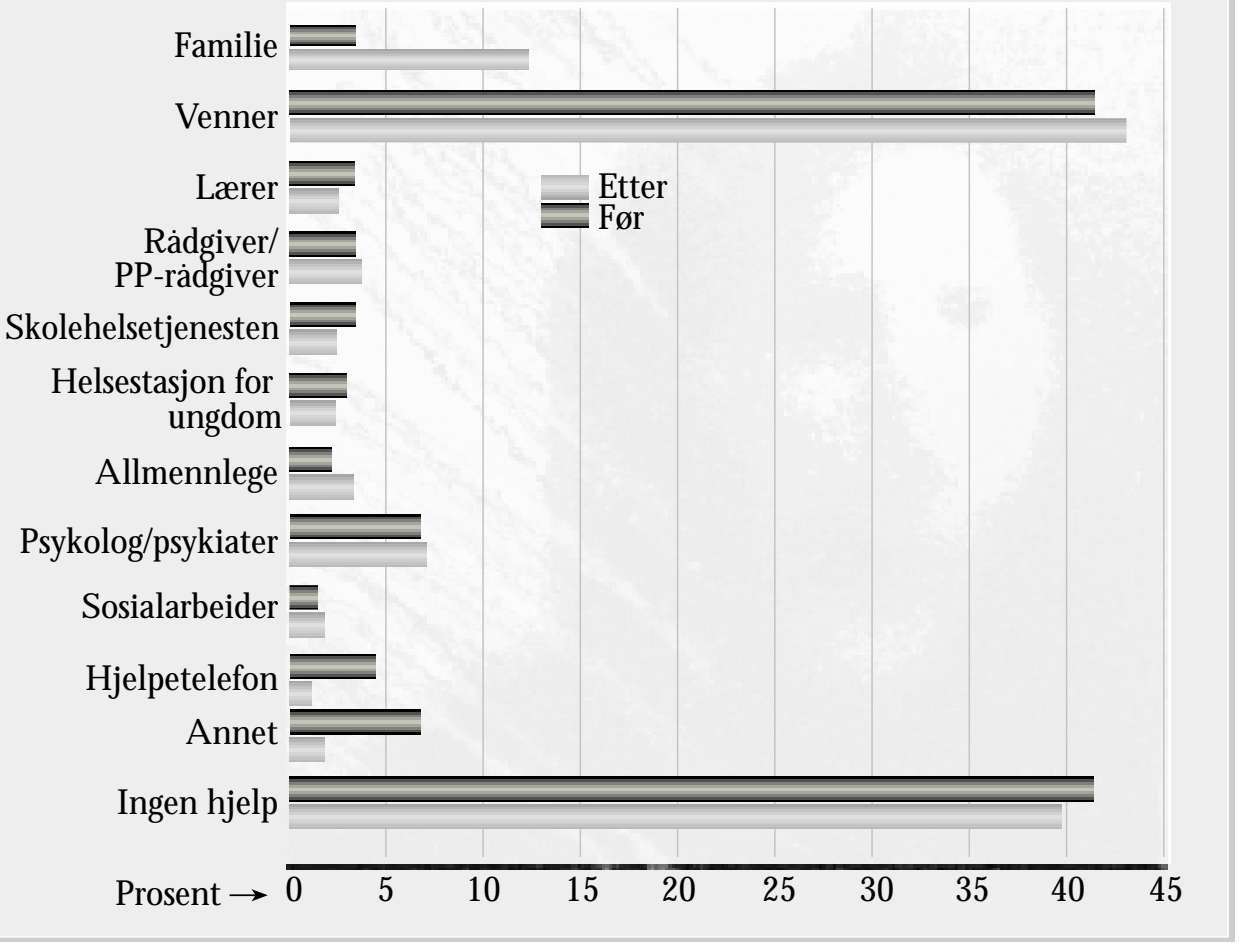


Resultatene viser med all tydelighet at det er venner som først og fremst er kjent med problemene både i forkant (110;41,4\%), og som prøver å støtte og hjelpe i etterkant (115; 43,2\%). Et fătall har vært i kontakt med skolens personale eller med allmennlege, mens 19 (7,1\%) fikk hjelp av psykolog eller psykiater etter den siste episoden. M ange har vært i kontakt med flere innen både behandlingsapparatet og nettverket, mens $110(41,4 \%)$ av elevene ikke hadde søkt noen form for hjelp før og 106 (39,9\%) ikke hadde mottatt noen form for hjelp etter den selvskadende episoden. Litt uventet, og i motsetning til tidligere undersøkelser, finner vi ingen forskjeller mellom gutter og jenters kontakt med hjelpere verken når det gjelder omfang av kontakt med ulike deler av nettverket eller det profesjonelle hjelpeapparatet.

Er det da slik at de som har størst problemer, er de som får profesjonell hjelp? V åre foreløpige analyser tyder ikke på at det er slik. N år vi sammenligner de 106 elevene $(39,9 \%)$ som ikke har fått noen hjelp med de 99 elevene (37,2\%) som bare har fått hjelp fra nettverket sitt og de $61(22,9 \%)$ som har hatt kontakt med en eller annen i det profesjonelle hjelpeapparatet (i tillegg til eventuelle kontakt i det sosiale nettverket), finner vi ikke signifikante forskjeller i symptomer på angst og depresjon mellom disse tre gruppene.

\section{Noen tanker om forebyggende arbeid i skolen}

Resultatene i denne undersøkelsen viser tydelig at skolen er en viktig arena for å forebygge selvdestruktiv atferd blant ungdom. D et er flere grunner til dette. O mfanget av villet egenskade er stort. $M$ ange har store problemer og har verken kontakt med det sosiale nettverket eller med profesjonelle. Det er oftest jevnaldrende kamerater som trår til og hjelper. Dessuten har villet egenskade blant ungdom sterk sammenheng med lav selvfølelse, et problem som skolen klart kan bidra til å redusere. (Y stgaard et al. 2003)

På slutten av spørreskjemaet ble elevene bedt om å svare på spørsmålet " $H$ va mener du kan gjøres for å hindre at unge mennesker tar overdose (med piller eller medisiner) eller skader seg selv på annen måte, som ved å kutte eller skjære seg?" De mange og innsiktsfulle svarene vi fikk, gjenspeiler fenomenets sammensatte natur og understreker behovet for ulike typer tiltak. O verskriftene som følger er typiske uttalel ser fra elevene, og de fremhever noen av de viktige områdene skolen kan konsentrere seg om.

\section{" $M$ ange skader kunne vært unngått med mindre mobbing - vi må ha bra klassemiljø!"}

A llerede i 1979 påviste R utter og medarbeidere i en banebryten de undersøkel se at et godt skolemiljø, eller skolens"ethos", ikke bare hadde betydning for skoleprestasjoner, men også for elevenes psykiske helse. Etter hvert har vi fått en rekke helsefremmen de prosjekter og tiltak for å bedre tilhørighet og trivsel i klassen og styrke selvtillit og mestring. En gjennomgang av norske skoleprosjekter viser at "Steg for steg", der målet er å redusere aggressiv atferd og styrke sosial kompetanse, er et av de mest brukte programmene (Kirke-, utdannings- og forskningsdepartementet 2000). Distribusjon av programmet, treningskurs og veiledning for lærere organiseres av $\mathrm{N}$ asjonalforeningen for folkehelsen. I dette nummeret av Suicidologi presenterer vi prosjektet "Zippy og vennene" (s. 16-18), som har som mål å lære 6-8-åringer å mestre hverdagsl ivets problemer og skape gode sosiale relasjoner mellom barna i klassen. Det daglige arbeidet for å styrke el evenes sosial e kompetanse og skape et godt integrerende skolemiljø bør være utgangspunktet eller selve grunnmuren i ethvert tiltak i skolen for å forebygge psykiske hel seproblemer.

\section{"F oreldre og lærere må ta mer ansvar} og virkelig bry seg - og gripe inn."

Det er tankevekkende at voksne i så liten grad er inne i bildet når ungdom påfører seg skade, særlig når de unge selv ønsker at voksne bryr seg mer. V åre funn bekreftes av flere tidligere undersøkelser (Rossow \& W ichstrøm 1997, Ystgaard 1993). M er kunnskap om omfanget av villet egenskade og psykiske lidelser og hvordan en kan hjel pe, kan her være ett av flere virkemidler for å øke voksnes årvåkenhet. Flere undervisningstilbud som 0 pplandsprosjektet (Johnsen \& Reinholdt 1996) og

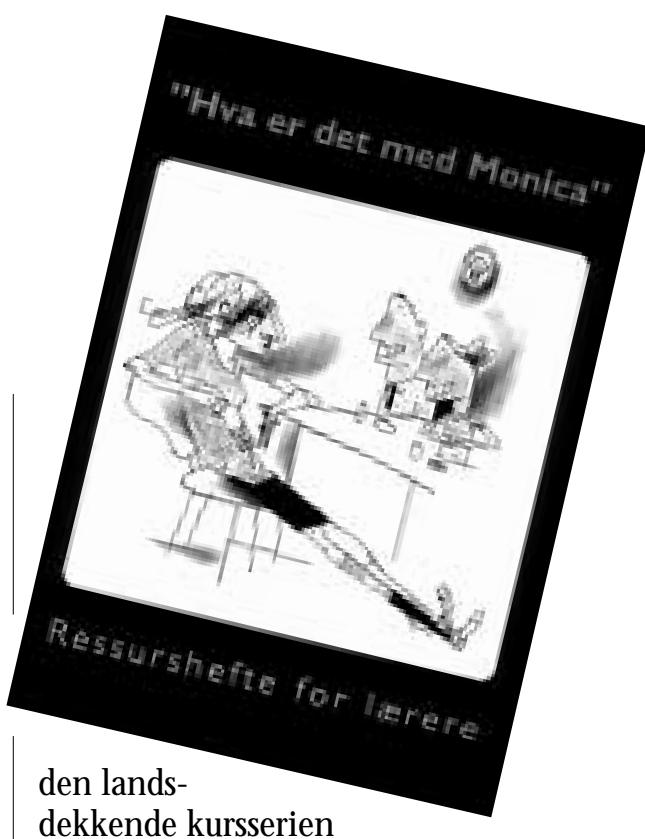

dekkende kursserien

"H va er det med M onica?", organisert av Stiftelsen Psykiatrisk O pplysning, er gode eksempler på kurs om selvmordsatferd og psykiske lidelser for skolens personale.

$M$ ange unge gjør imidlertid selvskadene hjemme, og de fleste foreldre vet ikke om at barna deres har påført seg selv skade. A ndre undersøkelser viser også at foreldre i liten grad vet om sine barns selvmordstanker og selvmordsforsøk (Breton et al. 2003). I den grad skolen fanger opp problemet, må dette alltid tas på alvor og regelen må være at forel drene koblesinn. Felles kurskvelder for lærere og foreldre vil kunne bidra til økt samarbeid mellom skole og hjem om disse problemene. I tillegg til å gi foreldre og lærere mer innsikt i problemet måtte målet med slike kurs være å gi dem trygghet og mot til å gripe inn. VIVAT kurset "Førstehjelp ved selvmordsfare", hvor en bearbeider egne holdninger og rollespiller vanskelige samtaler, er et eksempel på hvordan slike kurs kunne legges opp (Silvola 2001).

\section{"R edningen er venner, en god venn fungerer nok like bra som en psykolog og psykiater."}

Resultater fra CA SE-studien bekrefter tidligere undersøkelser: U ngdom betror seg først og fremst til venner. 0 gså før selvskadingen var det først og fremst venner som visste om problemene. Venner kan være til uvurderlig hjelp. Samtidig er det viktig at ungdom ikke får for stort ansvar dersom en venn har alvorlige selvmordstanker eller en alvorlig psykisk lidelse. Tidligere studier viser at ungdom er lite innstilt på å råde vennene sine til å søke profesjonell hjelp om de går med selvmordstanker. I en undersøkelse i videregående skole svarte bare $5 \%$ at de ville råde vennen sin til å søke slik hjelp om de ble betrodd selvmordstanker (Ystgaard 1993). 


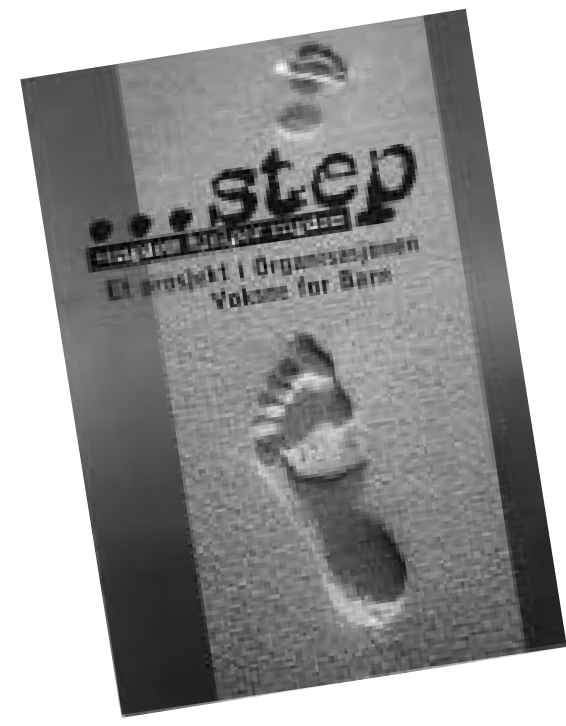

Prosjektet "STEP - ungdom hjelper ungdom" i regi av den frivillige organisasjonen "Voksne for Barn" er et godt eksempel på hvordan vi kan utnytte og understøtte den betydelige fellesskapsfølelsen som ligger i vennskap. STEP er en samtaletjeneste for ungdom hvor ungdom kan bistå yngre og jevnaldren de ungdom i spørsmål som berører hverdagslivets problemer, og hvor de i fellesskap kan reflektere over egne mestringsstrategier. En styrke ved dette prosjektet er at ungdom som rekrutteres for å bli samtalepartnere, får opplæring og blir kontinuerlig veiledet av fagfolk. De får også opplæring i å gi råd om hvordan man kan komme i kontakt med hjelpeinstanser i lokalsamfunnet.

\section{"Vi må lære mer om psykiske problemer,} og om hvor vi kan gå."

U ngdom som skader seg, tar i liten grad kontakt med skolens hjelpeapparat. En av grunnene til dette kan være at de fleste unge har liten kunnskap om hvor de kan få hjelp og hva slags hjelp det er muligå få (Y stgaard 1993). G rongprosjektet, V IPprosjektet (Veiledning og Informasjon om Psykiske lidelser hos ungdom) og O ppdal sprosjektet, omtal es i dette nummeret (s. 11-13) og er eksempler på tiltak for å gi ungdom kunnskap om psykiske problemer, mestring av kriser og kunnskap om hjelpeapparatet. En samlet erfaring fra prosjektene er at elevene er engasjerte og interesserte, og at behovet for mer kunnskap er stort. D et er derfor gledelig at flere skoler nå legger slike prosjekter inn i timeplanen. Kanskje denne opplæringen kan bidra til å fjerne tabuer og gjøre ungdom mer åpne for å søke hjelp når de har behov for det.

"D et hjelper ikke bare å si du må få hjelp. D et er slett ikke alle som tørr å oppsøke profesjonelle."
Villet egenskade utløses noen ganger av mer forbigående stress, an dre ganger kan det ligge mer alvorlige problemer og psykiske lidelser til grunn. Både denne og tidligere undersøkel ser viser at alvorlig angst og depresjon, rusmisbruk og ettervirkninger av traumatiske opplevelser som for eksempel seksuelle overgrep, kan prege mange selvskaden de unge. $\mathrm{N}$ oen trenger derfor omfatten de hjelp og behandling. For å sikre differensiert hjelp til selvskaden de ungdom er det nødvendig med godt samarbeid mellom skolen og andrelinjetjenesten. $M$ ange unge og foreldre må motiveres for å ta imot profesjonell hjelp. A ndre ganger kan hjelpen gis ved at den voksne som den unge har tillit til, får veiledning av profesjonelle. Et nytt samarbeidsprosjekt mellom barneog ungdomspsykiatrien og videregåen de skole viser hvordan samarbeidet mellom første- og andrelinjen kan styrkes, og hjelpen gjøres lettere tilgjengelig for elevene (Langaard 2002). En ansatt i barneog ungdomspsykiatrien ved $\mathrm{N}$ ic W aals Institutt hadde i prosjektperioden kontor på Sogn videregående skole. Skolehelsetjenesten og BU P samarbeidet daglig om vurdering og til rettel egging for differensi erte samtaletilbud til ungdom som kontakter skolehelsetjenesten. Evalueringen av prosjektet viser at ungdom ofte kom sammen og brukte mye tid på å "teste ut" de voksne. Selv om prosjektet i utgangspunktet var rettet mot jenter, var det etter hvert også mange gutter som tok kontakt. I løpet av prosjektperioden økte antallet henvendelser fra elever med til dels store problemer betraktelig.

\section{Konklusjon}

Villet egenskade er et vanlig problem blant ungdom og nødvendiggjør en variert og mål rettet innsats hvor skolen spiller en viktig rolle. Det er behov for mer kunnskap hos voksne og ungdom, styrking av voksnes involvering når ungdom har problemer, og lettere tilgang på profesjonell hjelp for dem som har behov for det. $M$ en fellesnevnere i alle tiltakene bør slik elevene utrykker det, være "å høre på oss og ta problemene våre på alvor" og "å gjøre det lettere å være en del av samfunnet selv om du har psykiske problemer".

\section{Litteratur}

Breton J, Tousignant M , Bergeron L. Parents underreport children's suicidal ideation and attempts. Journal of the A merican A cademy of $C$ hild \& A dolescent Psychiatry 2003; 41: 723-30.

G roholt B, Ekeberg 0 , W ichstrom L, H aldorsen T. Young suicide attempters: a comparison between a clinical and an epidemiological sample. Journal of the $A$ merican $A$ cademy of $C$ hild \& A dolescent Psychiatry 2000; 39: 868-75.

$H$ awton $K$, Rodham K, Evans E, W eatherall R. D eliberate self harm in adolescents: self report survey in schools in England. British M edical Journal 2002; 325: 1207-11.

ICD-10. D en internasjonale klassifikasjonen av sykdommer og beslektede helseproblemer. 10 . revisjon. O slo: Statens helsetilsyn [W H O ], 1998.

Johnsen T, Reinholdt N P. Selvmordsforebyggende arbeid $\mathrm{i}$ videregående opplæring. Rapport fra et utviklingsprosjekt i 0 ppland fylke. Lillehammer 1996.

Langaard K. Psykososial hjelp til unge jenter i et flerkulturelt miljø. 0 slo: $\mathrm{N}$ ic W aals Institiutt, 2002.

Rossow I, W ichstrøm L. N år nøden er størst - er hjelpen nærmest? $\mathrm{H}$ jelp og behandling etter selvmordsforsøk blant ungdom. Tidsskrift for Den norske lægeforening 1997; 117: 1740-43.

Rutter $M, M$ aughan $B$, M otimore P. O uston. Fifteen thousand hours. Bath: Pitman Press, 1979.

Silvola K. Førstehjelp ved selvmordsfare: $\mathbf{H}$ va kan folk uten helsefaglig bakgrunn gjøre? Suicidolog 2001; 6: 25-6

V urdering av program og tiltak for å redusere problematferd og utvikle sosial kompetanse. 0 slo: Kirke-, utdannings- og forskningsdepartementet, Barne- og familiedepartementet, 2000. (Rapport 2000) http://odin.dep.no/archive/ kufvedlegg/01/ 01/probl029.pdf

Ystgaard M . Sårbar ungdom og sosial støtte. 0 slo: Senter for sosial nettverk og helse, 1993.

Ystgaard M. N ytt multisenterprosjekt om villet egenskade blant barn og unge i Europa. Suicidologi 2001; 6: 14

Ystgaard M, Reinholdt N P, H usby J, M ehlum L. Villet egenskade blant ungdom. Tidsskrift for $D$ en norske lægeforening $2003 \mathrm{nr}$. 16 (28/8)

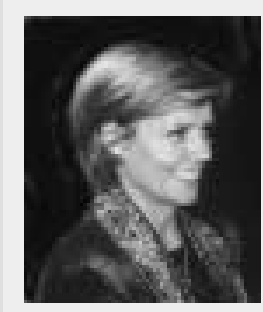
M ette Y stgaard er cand. paed. og førsteamanuensis ved Seksjon for selvmordsforskning og -forebygging. H un har mangeårig erfaring fra $\mathrm{pp}$ tjenesten. H ennes forskning er særlig konsentrert om selvmordsatferd $i$ et

stressmestringsperspektiv. H un er nasjonal prosjektleder for $\mathrm{C}$ hild and A dolescent Selfharm in Europe (CA SE). 